STUDI

FRANCESI

\section{Studi Francesi}

Rivista quadrimestrale fondata da Franco Simone

143 (XLVIII | II) | 2004

Varia - fasc. II - maggio-agosto 2004

\title{
Raphaelle Legrand, Francine Wild, Regards sur l'Opéra-Comique. Trois siècles de vie théâtrale
}

\section{Véronique Montémont}

\section{(2) OpenEdition}

1 Journals

\section{Édition électronique}

URL : https://journals.openedition.org/studifrancesi/39522

DOI : 10.4000/studifrancesi.39522

ISSN : 2427-5856

Éditeur

Rosenberg \& Sellier

\section{Édition imprimée}

Date de publication : 1 décembre 2004

Pagination : 383-384

ISSN : 0039-2944

\section{Référence électronique}

Véronique Montémont, « Raphaelle Legrand, Francine Wild, Regards sur l'Opéra-Comique. Trois siècles de vie théâtrale », Studi Francesi [En ligne], 143 (XLVIII | II) | 2004, mis en ligne le 30 novembre 2015, consulté le 19 mai 2021. URL : http://journals.openedition.org/studifrancesi/39522 ; DOI : https:// doi.org/10.4000/studifrancesi.39522

Ce document a été généré automatiquement le 19 mai 2021.

\section{(c) $($ ) $\odot$}

Studi Francesi è distribuita con Licenza Creative Commons Attribuzione - Non commerciale - Non opere derivate 4.0 Internazionale. 


\title{
Raphaelle Legrand, Francine Wild, Regards sur l'Opéra-Comique. Trois siècles de vie théâtrale
}

\author{
Véronique Montémont
}

\section{RÉFÉRENCE}

Raphaelle Legrand, Francine Wild, Regards sur l'Opéra-Comique. Trois siècles de vie théâtrale, Paris, CNRS Editions, «Sciences de la Musique», 2002, pp. 290.

Dans cet ouvrage richement illustré, enrichi de multiples témoignages, qui retrace l'histoire de l'Opéra-Comique du début du XVIII siècle à nos jours, trois chapitres intéressent directement la première moitié du XIX siècle.

2 Le premier, intitulé «Jadis et aujourd'hui» (pp. 93-106), couvre la période qui va de 1801 à 1814. Il relate comment la Salle Favart et le Théâtre Feydeau, occupés par deux troupes rivales, sont alors réunis sous le nom de Théâtre National de l'Opéra-Comique. Cette nouvelle organisation va de pair avec un changement de répertoire, s'orientant vers des œuvres plus divertissantes: Les Visitandines de Devienne connaissent ainsi un vif et durable succès. Bonaparte est à l'origine de ce regroupement, car il lui permet, au moyen de l'attribution de privilèges, de mieux contrôler les théâtres. Ce qui, par ricochet, aboutit au retrait de certaines pièces et au retour rapide à l'ancien répertoire.

Le deuxième chapitre qui retiendra notre attention (pp. 107-120) concerne les deux décennies suivantes, de 1814 à 1832 . Intitulé «L'intrigue au château», il traite de la période difficile que connaît ce théâtre sous la Restauration: un déménagement, des changements de direction et des revers financiers s'ajoutent à la concurrence sévère du Théâtre des Italiens, dont Rossini prend la direction en 1824 et qui fait l'objet d'un véritable engouement à Paris. Pourtant, le compositeur Boïeldieu reste fidèle à l'OpéraComique et connaît un très grand succès en 1825 avec La Dame blanche, sur un livret de Scribe. Hérold, dont la Marie (1826) enchante Nerval, contribue avec Auber à 
l'enrichissement du répertoire de cette scène. En revanche, les sociétaires sont débordés par des problèmes de gestion, leur répertoire est amplement pillé par d'autres théâtres, le nouveau bâtiment de la place Ventadour endette durablement la compagnie et manque de l'acculer à la ruine.

4 Les années 1832-1852, évoquées dans le chapitre suivant («Adam, Auber: "Lequel?"», pp. 121-133), marquent un retour à l'équilibre financier et voient l'abandon de la ruineuse salle Ventadour au profit de Favart en 1840. Ce bâtiment, édifié sur les ruines de l'ancienne salle, détruite par un incendie en 1838, bénéficie d'une excellente acoustique qui met en valeur le travail des chanteurs. Durant ces années, le couple Auber-Scribe compose un grand nombre d'œuvres, admirées de Nerval comme de Wagner: on loue à la fois le caractère populaire de la musique du compositeur et sa capacité à insuffler une énergie nouvelle au genre de l'opéra-comique. L'autre figure charismatique du moment est celle d'Adolphe Adam, auteur du célèbre Postillon de Longjumeau qui faisait les délices de Berlioz. 